\title{
Hoist by our own petard: Backing slowly out of religion and development advocacy
}

Author:
Jill Olivier' ${ }^{1}$
Affiliation:
${ }^{1}$ Health Policy and Systems
Division, School of Public
Health and Family Medicine,
University of Cape Town,
Cape Town, South Africa
Corresponding author:
Jill Olivier,
jill.olivier@uct.ac.za
Dates:
Received: 12 June 2016
Accepted: 18 Aug. 2016
Published: 24 Oct. 2016
to read online.
How to cite this article:
Olivier, J., 2016, 'Hoist by our
own petard: Backing slowly
out of religion and
development advocacy',
HTS Teologiese Studies/
Theological Studies $72(4)$,
a3564. http://dx.doi.
org/10.4102/hts.v72i4.3564
Read online:
Copyright:
@ 2016. The Authors.
Licensee: AOSIS. This work
is licensed under the
Creative Commons
Attribution License.

There has been a massive advocacy movement over the last 15 years that has sought to advance the case of religion into view of decision-makers in the international development sector. This advocacy effort has been dispersed and not centrally organised, and is made up of the efforts of multiple development actors, religious institutions, researchers and others. This article shows how this advocacy approach has been highly successful in increasing acceptance of the fact that religion is relevant to development, and religious communities and institutions make contributions to the development effort - and this acceptance can now be seen at the highest levels. However, the article highlights several challenges that have come with this advocacy approach. It therefore supports urgent reflection on the direction of this advocacy going forward and suggests that major and uncomfortable adaptations might now be required.

\section{Introduction}

In January 2006, part of a group of researchers, I was gratefully sitting in the shade on a very shaky wooden bench at the back of a small community church in Zambia. The following is an observation narrative written in my notebook:

\footnotetext{
The religious leader stands up and, turning to face the rest of the community, says in a forceful voice: 'religion contributes love', and sits down, crossing his arms. There is a pause in the discussion. Perhaps not getting the response he had expected, he stands up again, and says, 'love is support ... and hope', and sits down ... only to leap up to his feet again and, throwing his hands up in the air, but with a questioning lilt to the end of his sentence, says, 'love is home-based care and clinics?' At which point his audience nods and murmurs, 'Amen'. (Observation notes, De Gruchy et al. 2006)
}

This is a familiar narrative for those who have conducted research seeking to understand the contribution of religion in development contexts - as is the struggle to articulate this contribution and the tension between tangible and intangible forms of contributions (also called 'religious assets'). However, there is also a complex international backdrop to this local narrative. We were a multinational team of researchers from northern (American) and southern (South African) academic institutions conducting a mapping study for the World Health Organisation (WHO), seeking to understand and measure the contribution of religion to HIV and AIDS in Zambia and Lesotho (see De Gruchy et al. 2006). We were there because we had made a strong argument to the WHO that, contrary to the common view of international development and global health institutions, religion and religious entities in Africa were significant, but that no one seemed to know what this contribution was. Several senior development actors were arguing that religious institutions were worryingly invisible to the international development agenda, but at the same time acknowledging there was no robust evidence that convincingly made this argument for international policy- and decision-makers. From a research standpoint, we argued, '[t]he full scope of the religious health system is unknown, and what information there is, remains disparate and often conflicting' (De Gruchy et al. 2006:20). Rev. Canon Ted Karpf, then a senior staff member at the WHO, had also put effort into campaigning for this research to be supported and branded as a WHO study (at the time, an almost unheard-of achievement).

Fast-forward only a few years, and today this backdrop has changed dramatically. For example, at a conference held at the impressive centre of international development power, the World Bank in Washington, DC, in July 2015, several international development leaders stood up and acknowledged that religion clearly contributed to sustainable development. World Bank President Jim Yong Kim spoke of the World Bank's intentions to continue expanding their partnership with religious institutions: 'Faith-based organisations and religious communities

Note: This article forms part of the special collection on 'Engaging development: Contributions to a critical theological and religious debate' in HTS Teologiese Studies/Theological Studies Volume 72, Issue 4, 2016. 
are often doing the essential work on the frontlines of combatting extreme poverty, protecting the vulnerable, delivering essential services and alleviating suffering' (Joint Learning Initiative on Faith and Local Communities 2015:6). The conference proceedings make the following opening claim:

The question is no longer whether religion matters for development. There is compelling evidence that faith-based and religious organisations contribute added value in the field of development - especially in health, education, and disaster relief. The question now is: how to systematically include the potentials of religious organisations for development, and according to what principles and criteria? (2015:7)

In just over a decade, the public discourse in the international development sector had shifted from the contribution of religion to development being an unknown to a commonly accepted fact. In this article, this rapid shift is explored. As will be demonstrated, we have moved from an era in the 1990s when religion was largely invisible to the development sector - to a defined 'tribe' of industry, seemingly with influence at some of the highest levels of development agenda-setting. I argue that this shift has largely been the result of a concerted (if perhaps not coherent or organised) effort that is framed here as 'religion and development advocacy', an effort that has effectively combined leadership-based advocacy with research and evidence-gathering.

This article focuses on the international development arena, although it also relates closely to the other articles in this issue with a South African focus. Much of this advocacy and the gathering of evidence to support this effort has emerged from Africa, and South Africa in particular. For example, some of the strongest teaching and research efforts on this have emerged from initiatives such as the Unit for Religion and Development Research at Stellenbosch University, the Theology and Development Programme and the Collaborative for HIV and AIDS, Religion and Theology (CHART) at the University of KwaZulu Natal, and the African and/or International Religious Health Assets Programme (ARHAP/IRHAP) out of the University of Cape Town.

In this article, material is synthesised from two large South African literature review projects. The first is the aforementioned CHART (see Olivier et al. 2016), which has been systematically reviewing materials on religion and HIV or AIDS (in English, French, Spanish and German, with materials spanning 1985-2016). The second is a database run by IRHAP on religion and public health in development contexts, with English and French materials spanning 19602016 (see Olivier, Schmid \& Cochrane 2016). Both of these databases make it possible to track trends in the literature relating to religion and development. It should be noted that both databases are unavoidably biased towards Christian, sub-Saharan African, HIV or AIDS-related and Englishlanguage materials as a result of the same bias in the existing published literature.

\section{A very brief history of 'religion and development'}

The history of the (re)emergence of religion onto the development agenda has been well covered. An assessment of the two databases shows over 4000 articles addressing religion and development, of which 86 articles are directly reflecting on this emergence of religion in development (see Belshaw, Calderisi \& Sugden 2001; Botchwey 2007; Buijs \& Kasambala 2008; Carbonnier 2013; Clarke 2006, 2007; Deneulin \& Rakodi 2011; James 2011; Krige 2008; Marshall \& Keough 2005; Marshall \& Van Saanen 2007; Pallas 2005; ParaMallam 2006; Platteau 2008; Rakodi 2007; Rew 2011; TerHaar \& Ellis 2006; Tomalin 2015).

In the 1990s, religion was almost invisible on the development sector map. The common reasons given for this are that modernism and the secularisation thesis created an assumption that with development, progress and increasingly 'rational' thinking, religion would become less relevant. In addition, international development (as a field and practice) emerged in northern settings where there was a clear separation of state and religion, so these assumptions carried over to practice in development settings (even if this division was not obvious in most development states). Not only did this result in religion 'blindness' within the international development sector, but also at times a substantial resistance to religion. Melkote and Steeves (2001) argue that modernisation thinking held (and still holds) an inherent bias towards religion, where religions are seen as obstacles to progress. Development actors have consistently displayed signs of 'religionophobia', on the extreme end claiming that religious institutions are primarily interested in proselytisation and therefore should not be supported with development funding and on the other end of the spectrum simply saying nothing at all. This disconnect was not one-sided, as many religious institutions and leaders similarly shied away from engagement with the international development sector (although of course not from the activities that are now called 'development practice' at a local level). This reluctance often stemmed from suspicion of the power dynamics within the development sector and fears of being hijacked for development agendas - concerns that linger today (see below).

Then, at the turn of the 21st century, mainly from within the international development sector, there emerged a small handful of actors - mostly individuals who had a personal conviction that religion needed to be taken seriously (practically and intellectually) within international development. These actors began to make efforts to forward this agenda, often against strong opposition. In this period, the suggestion that religion was important to development was a jarring experience for many (Marshall 2001). Katherine Marshall is a good example of one of these individuals working for over three decades at the World Bank, she led dialogue and advocacy on the interface between religion and development from within the World Bank and continues to 
do so now from the World Faiths Development Dialogue (WFDD, see Marshall 2001; Marshall \& Van Saanen 2007). Other examples include Azza Karam, who has led on integrating religion into development practice out of the United National Population Fund (UNFPA, see Karam 2010; Karam et al. 2015); Sally Smith, who has led on engagement with religious communities out of the Joint United Nations Programme on HIV and AIDS (see Olivier \& Smith 2016); Sandra Thurman and her work from within the United States Agency for International Development (USAID) and the US President's Emergency Plan for AIDS Relief (PEPFAR, see Blevins \& Griswold 2014); or Christoph Benn, who has held a secular position as Director of External Relations at the Global Fund to fight AIDS, Tuberculosis and Malaria, but who has consistently conducted quiet diplomacy, raising the profile of religious institutional engagement in health and development (see Benn 2003; Global Fund 2008). Such individuals (as well as many others) began to make inroads at the international development level. Their roles involved hosting meetings, facilitating dialogue, publishing, and sponsoring or leveraging the sponsorship of research that was targeted at gathering evidence on the contribution of religion to international development (see Olivier 2010). These multiple roles are clearly visible when tracking such names through the two databases that contain both academic and grey literature such as reports and conference proceedings.

Two major influences gave impetus to the efforts of such individuals and drew more voices rapidly into this advocacy space. Contrary to the predictions of modernist and secular theories, religion began to re-emerge into public life. Religious movements flourished, and religion reappeared in the political sphere on a global scale (exemplified by the rippled effects of the 11 September 2001 attacks in the USA). The second major influence was the HIV and AIDS pandemic and the rise of the HIV and AIDS development 'industry'. HIV and AIDS emerged as a massively complex social problem that forced a greater engagement with complex social issues. This opened a door for mainstream inquiry into the influences of religion on community - especially as religion was raised as a key confounding factor for HIV intervention early in the pandemic. The enquiry here was focused mainly on questions about the role of religion in individual health-related decision-making and questions about whether religious communities and institutions held 'untapped resources or assets' that could be leveraged by a global community fighting against HIV and AIDS (see more on this below; see also Olivier \& Smith 2016; Olivier \& Wodon 2012).

With secularisation challenged, religion reappearing in public life and the challenges of HIV and AIDS bringing new opportunities for engagement, there was suddenly a new 'open door opportunity' (as you say in policy work) for those who had been reflecting that religion needed to be taken more seriously in development practice. This is what is being termed here 'religion and development advocacy'; the deliberate and sustained effort to move 'religion' (religious influences, religious communities, leaders and institutions) onto the development agenda - or as you might commonly hear at international development meetings, 'getting religion on the development map' or 'getting religious institutions to the development table'.

Great care needs to be taken with the term advocacy, as it has different meanings (and I treat it with added caution, since I reflexively acknowledge having been a part of this advocacy effort, so this article is in large part a self-critique). Advocacy is commonly framed as an act of pleading or arguing in favour of something, such as a cause, idea or policy (see Bateman 2000, with the note that pleading here is meant as reasoned argument, not pleading for mercy). The religion and development advocacy addressed here has been a broadscale (reasoned and 'rational') argument that religion needs to be taken into account by international development actors, decision-makers and funders. This advocacy has not been the responsibility of a single group - but instead has been a dispersed drive emerging from within development institutions, religious institutions, academic institutions (varied disciplines, not just religious studies) and most strongly out of large international religious development agencies. This advocacy has been shaped by all these different voices. It is therefore made up of arguments such as the need for more religious representation in development decisionmaking spaces; that more resources should be fairly distributed to religious institutions engaged in development work; that religious and development scholars should dialogue more frequently; and that more research on religion and development should be supported and published (these claims are based on an analysis of the literature reviewed in these two databases). In Table 1, a sample of publications is provided, where the title demonstrates to the reader the intent of the text.

These publications are a small sample of literally thousands of articles, reports and other items shaping this religion and development advocacy agenda. The sheer volume of publications that have emerged over the last 15 years is one indicator of the strength and resourcing of this advocacy effort. The HIV and AIDS industry had a particular influence here, adding interest and resourcing for research and publication. For example, of the roughly 4000 items relevant to religion and development in the two databases, two-thirds of these relate to HIV and AIDS. A particular trend in the religion and HIV and AIDS literature is for sponsored reporting on the 'religious response to HIV and AIDS' (see Olivier \& Smith 2016). In this particular literature (which is made up of several hundred reports, mostly emerging between 2004 and 2010), the intention appears to be the reporting and evidencing of the 'unacknowledged contribution' of religious communities and institutions to HIV and AIDS efforts, and it is usually sponsored by or has affiliation to an international religious development agency or institution (Olivier \& Smith 2016; Olivier \& Wodon 2012). For example, one of the most influential reports in this cluster was an early study conducted by Geoff Foster (2004) for the World Conference of Religions for Peace and the United 
TABLE 1: Sample of publications feeding religion and development advocacy.

\begin{tabular}{|c|c|c|c|}
\hline Year & Author/reference & Institution & Title \\
\hline 2001 & Belshaw et al. & World Bank & Faith in development: Partnership between the World Bank and the churches of Africa \\
\hline 2001 & Bonney \& Hussain & DFID & Faith communities and the development agenda \\
\hline 2005 & Woldehanna et al. & Global Health Council & $\begin{array}{l}\text { Faith in action: examining the role of faith-based organisations in addressing HIV or } \\
\text { AIDS - a multi-country key informant survey }\end{array}$ \\
\hline 2006 & Taylor & Tearfund & $\begin{array}{l}\text { Working together? Challenges and opportunities for international development } \\
\text { agencies and the church in the response to AIDS in Africa }\end{array}$ \\
\hline 2006 & De Gruchy et al. & ARHAP for the WHO & Appreciating assets: The contribution of religion to universal access in Africa \\
\hline 2008 & Global Fund & Global Fund & Report on the involvement of faith-based organisations in the Global Fund \\
\hline 2008 & Kessler \& Arkush & The Woolf Institute of Abrahamic Faiths & $\begin{array}{l}\text { Keeping faith in development: The significance of interfaith relations in the work of } \\
\text { humanitarian aid and international development organisations }\end{array}$ \\
\hline 2008 & UNFPA & UNFPA & Culture matters: Lessons from a legacy of engaging faith-based organisations \\
\hline 2008 & Schmid et al. & $\begin{array}{l}\text { ARHAP for the Bill and Melinda Gates } \\
\text { Foundation }\end{array}$ & The contribution of religious entities to health in sub-Saharan Africa \\
\hline 2009 & Vitillo & Catholic Church & $\begin{array}{l}\text { Faith-based responses to the global HIV pandemic: Exceptional engagement in a } \\
\text { major public health emergency }\end{array}$ \\
\hline 2010 & CIFA & Centre for Interfaith Action & $\begin{array}{l}\text { Many faiths, common action: Increasing the impact of the faith sector on health and } \\
\text { development - a strategic framework for action }\end{array}$ \\
\hline 2010 & Karam & UNFPA & $\begin{array}{l}\text { The United Nations Populations Fund's legacy: engaging faith-based organisations as } \\
\text { cultural agents of change for the MDGs }\end{array}$ \\
\hline 2011 & Leurs et al. & University of Birmingham for DFID & Mapping the development activities of faith-based organisations in Tanzania \\
\hline 2012 & WFDD & Tony Blair Faith Foundation & Global health and Africa: Assessing faith work and research priorities \\
\hline 2014 & Blevins \& Griswold & Interfaith Health Program (IHP) for PEPFAR & $\begin{array}{l}\text { Essential partners: The scope of the contributions of faith-based health systems to HIV } \\
\text { prevention, treatment, and support in Kenya }\end{array}$ \\
\hline
\end{tabular}

Source: This sample was selected by the author from the IRHAP and CHART databases

Nations Children's Fund, which descriptively mapped (and used 'matchbox calculations' to count) the 'response by faithbased organisations (FBOs) to orphans and vulnerable children' in six African countries.

In terms of academic publishing, there has been a rapid increase in the number of publications relating to religion and development, as well as in the number of publications on religion and development in mainstream development or global health publications. For example, Development in Practice has now published several special issues on religion and development (see Leurs 2012); and astoundingly (for those who know how unpopular religion was at the turn of the century), The Lancet published an entire special edition on religion and health in development contexts in 2015 (see Karam et al. 2015; Olivier et al. 2015).

There are other indicators of success for this religion and development advocacy effort. Before 2000, apart from some of the early work by those such as Katherine Marshall at the World Bank, there was very little organised representation of religious groups on the international development scene. To clarify, this is not to say that religious institutions were not involved in what is now called development work - or that there were not certain groups involved in high-level collaboration and engagement with policymakers. For example, the World Council of Churches and the Catholic Church (on behalf of the Catholic development agencies) have been engaged in high-level policy engagement for decades (see Dicklitch \& Rice 2004; Duff et al. 2016). However, such engagement was limited compared with the scope of religious entities now represented at the international development table. Today it is common to see religious institutions represented at high-level meetings such as the United Nations General Assembly; for the head of development institutions to hold publicised meetings with religious leaders; or for international conferences on 'religion and development' to be hosted within the halls of international development agencies (see Boehle 2010; Duff \& Buckingham 2015). In fact, the databases show regular international conferences on religion and development. For example, the conference mentioned earlier (held in July 2015 at the World Bank) was co-hosted by the World Bank Group, the German Federal Ministry for Economic Cooperation and Development, USAID, the UK Department for International Development (DFID), GHR Foundation, World Vision and the JLIF\&LC (see JLIF\&LC 2015). A few months later in February of 2016, another conference was hosted by the German government titled 'Partners for change - religions and the 2030 agenda', where the German government presented a 5-year strategy on the role of religion in German development policy and launched a new network called the 'International Partnership on Religion and Sustainable Development' (PaRD, see Duff et al. 2016). In 2000 there were only a few networks operating at an international scale focusing on collaboration relating to religion and development. Today there are hundreds of such networks and networking institutions (Table 2 provides a sample).

In 2000, it was difficult to find an academic institution engaged in teaching religion and development. There are now several postgraduate teaching programmes formally instituted as degree programmes on religion and development, for example, in the USA (e.g. Emory or Georgetown University), in Africa (e.g. the University of Stellenbosch or KwaZulu Natal) and in Europe (e.g. the University of Utrecht, Glasgow, Edinburgh, Leeds or Birmingham). 
TABLE 2: Sample of networks engaged in religion and development advocacy.

\begin{tabular}{|c|c|c|}
\hline Institutions & Networks & $\begin{array}{l}\text { Academic or research } \\
\text { networks }\end{array}$ \\
\hline $\begin{array}{l}\text { Ecumenical Advocacy } \\
\text { Alliance }\end{array}$ & $\begin{array}{l}\text { Agha Khan Development } \\
\text { Network }\end{array}$ & $\begin{array}{l}\text { Collaborative for HIV and } \\
\text { AIDS, Religion and Theology }\end{array}$ \\
\hline $\begin{array}{l}\text { Ecumenical HIV/AIDS } \\
\text { Alliance }\end{array}$ & $\begin{array}{l}\text { African Christian Health } \\
\text { Association Platform }\end{array}$ & $\begin{array}{l}\text { International Religious } \\
\text { Health Assets Programme }\end{array}$ \\
\hline $\begin{array}{l}\text { Lutheran World } \\
\text { Federation }\end{array}$ & $\begin{array}{l}\text { International Partnership } \\
\text { on Religion and Sustainable } \\
\text { Development }\end{array}$ & $\begin{array}{l}\text { Knowledge Centre Religion } \\
\text { and Development }\end{array}$ \\
\hline $\begin{array}{l}\text { Tony Blair Faith } \\
\text { Foundation }\end{array}$ & $\begin{array}{l}\text { Joint Learning Initiative of } \\
\text { Faith and Local }\end{array}$ & $\begin{array}{l}\text { Unit for Religion and } \\
\text { Development }\end{array}$ \\
\hline $\begin{array}{l}\text { World Council of } \\
\text { Churches }\end{array}$ & Communities & \\
\hline $\begin{array}{l}\text { World Faiths } \\
\text { Development Dialogue }\end{array}$ & $\begin{array}{l}\text { UN Inter-Agency Task Force } \\
\text { on Engaging with } \\
\text { Faith-Based Actors }\end{array}$ & \\
\hline
\end{tabular}

Source: Sample selected by the author, drawn from the CHART and IRHAP databases

Another important and contentious issue is whether the success of religion and development advocacy can (or should) be assessed on whether the percentage of financial commitment (donor funding) to religious institutions has increased. There have been several attempts to substantiate this argument (in either direction). However, all such efforts show major challenges in tracking financial data down to utilisation level and in separating out religious from secular institutions within financial datasets (more on this below). The question of whether the so-called faith sector has received its fair share of development aid remains highly charged and largely unanswered (see Haakenstad et al. 2015; Oliver and Wodon 2014; Thomas 2004). In general terms, several assessments show that religious institutions have seen a significant increase in international development aid from their pre-2000 levels. Reasons for this include a general increase in HIV and AIDS funding around 2000-2004 and the early stance of PEPFAR, launched in 2002, which profiled religious institutions and entailed particular funding for religious activities (Formicola, Segers \& Weber 2003; PEPFAR 2009). However, one of the underlying drivers of this can surely be ascribed to the religion and development advocacy effort, which has publicly claimed that religious institutions are working for development but are not being fairly compensated for that work (see Lee et al. 2003; Taylor 2005a, 2005b, 2006). In fact, the most obvious evidence of the advocacy effect are the reactionary reports published by the donors. Said differently, unless the advocacy had been effective, there would have been no reason for institutions such as PEPFAR, USAID, UNFPA, DFID, the Global Fund, or the World Bank to publish reports whose main purpose is to clarify that they are partnering with and funding religious institutions (see Belshaw et al. 2001; DFID 2006; Global Fund 2008; PEPFAR 2009; UNFPA 2008).

\section{Dead-ends for religion and development advocacy}

All of this seems remarkable and a worthy cause for celebration for those who have been working tirelessly to bring religion to the attention of the international development sector. However, several questions and confusions persist. Firstly, there are several concerns about how genuine this acceptance of religion is within the international development sector. That is, as shown above, there is certainly a massively increased visibility and surface-level collaboration. However, is this a publicitylevel or a genuine acceptance? For example, it is widely noted that 'religionophobia' lingers within the international development sector. Canon Ted Karpf (mentioned earlier) notes:

While it would appear that these separate movements are converging ... I regret to tell you that they are not ... there are several of us in the UN and intergovernmental system who have been successful in moving the door ajar ... the fact remains that religious health assets are a 'hard sell' for many ... simply put, the cultural environment is still hostile towards neutral, and only occasionally welcoming ... (Karpf in WHO-CIFA 2009:12-13)

In fact, at many of those international high-level meetings, it has been observed that very often it is the 'same old' actors engaged in this dialogue and that it is possible that this advocacy has stagnated. Certainly high-level development leaders have been reached, but operational and other staff remain absent from such meetings (this is a personal observation that is open to challenge). Ager and Ager (2016) note that in the post-secular period, while the consideration of religion and religious actors has become explicitly mainstream at the international level, international development continues to be attached to the modernist, secular framing of development. Likewise, Olivier and Wodon (2012) argue that while the international policy environment may have moved towards a more interested attitude towards religious institutions, this increased attention and literature has not resulted in much policy change, specific implementation strategies or targeted operational strategies that can be enacted.

One of the responses to this concern within the religion and development advocacy effort has been to suggest that 'religious literacy' is lacking within development institutions, and some programmes have been put into effect to attend to this (see Duff et al. 2016). While it seems likely that improved literacy would be useful, it is necessary to question how successful such efforts are in shifting something as embedded as a powerful secular or modernist framing within the development sector. What alternatives might have been considered without the driving force of the advocacy effort shaping the agenda? How much further can extremely highlevel (and costly) engagements take the advocacy effort - and what would it take to translate the affirmations made at these levels down to operational change within development practice (see Olivier 2010)?

One of the most prevalent responses to such questions is that more (and better) evidence is needed. The emergence of this 'evidence discourse' has been analysed in detail elsewhere (see Olivier \& Wodon 2012a, 2012b). In brief, the calls for more evidence within the advocacy effort have been framed in two main ways. Arguments have been made that, firstly, more 'mapping' is required, to evidence the contribution of religious communities and institutions to development and, secondly, that evidence needs to be built to show the comparative (distinctive) advantages of religious engagement in development. Some progress has been made in mapping 
the landscape of potential religious assets (see e.g. the research addressing the religious response to HIV or AIDS or the number of mapping studies in Table 1). However, even that basic act has had unintended consequences. The efforts to map the religious sector so that the development world can acknowledge them, and speaking in the language of 'assets for development' has, in hindsight, been a doubleedged effort. It may have been necessary for high-level advocacy (and appears to have been effective in this role), but many religious institutions are displaying increased discomfort at being mapped and treated in an 'instrumental way' by the international development sector (Olivier \& Paterson 2011). One of the challenges has been that the advocacy effort has presented religious tangible and intangible assets as under-utilised resources available for development efforts. The development sector has swiftly accepted this offer, utilising an econometric language of 'exploitation'. For example, the World Bank says, 'the role of African FBOs in combating HIV and AIDS is widely recognised as having growing significance but, at the same time, one which is not fully exploited, given the influence and reach of FBOs in African societies' (World Bank 2004:1). This statement shows both the success of the advocacy effort (that the World Bank made this acknowledgement), and the simultaneous discomfort that arises from the idea of being exploited for development goals. Such narrative warrants a full discourse analysis, as there are issues of power and authority underpinning this (see Olivier 2010). Perhaps those (of us) who engaged in this advocacy effort need to take more responsibility for having initially put religious assets 'on the plate' of international development - resulting in this discomfort, which now is very difficult to fix.

The advocacy around the comparative advantages of religious communities and institutions is even more challenging (and possibly regretful). Commonly stated comparative strengths or advantages that are claimed in the advocacy discourse are as follows: infrastructure; reach and access; that they provide services in inaccessible areas; that they have access to dedicated volunteers and educated leadership; that they have unique credibility, trust and acceptance in communities; that they have well-developed networks extending from international to grassroots communities; that they provide a special kind of care; or that they have particular resilience and durability (Olivier \& Wodon 2012a). For example, Rev. Gideon Byamugisha (another prominent advocacy figure) was quoted in 2004 in a WHO HIV and AIDS brief as saying:

We have a unique presence and reach within communities. We have unique structures and programmes that are already in place. We are available. We are reliable. And we are sustainable. (WHO 2004:3)

If you take a moment to consider the trajectory of the advocacy effort, it is obvious how this discourse about comparative advantages became so prominent. Those driving this effort felt there was a need to advocate for the value of religious communities and institutions - and it is generally accepted that these strengths are likely true in some contexts. However, it has been noted repeatedly that these comparative strengths are severely under-researched and today are still largely impossible to substantiate (see Olivier \& Wodon 2012a; Olivier et al. 2015). It is rather astounding that, in the face of thousands of articles that make the claim of comparative advantages, there are in fact only a very small handful of studies that actively compare equivalent religious and 'secular' institutions or development programmes. For example, there are a few that are focused on health service information (comparing religious and public health service provision; Olivier et al. 2015) and a handful in the USA (such as Kearns, Park \& Tanjoski 2005, who compare religious and secular community service corporations in Pittsburgh, PA). However, neither of these would be considered directly relevant to the development sector. There are a few other indirect hints at comparative differences in some development-relevant studies. For example, Anchita Ghatak (2006) addresses the activities of two secular nongovernmental organisations (NGOs) engaging on women's health in India. She argues that although this work absolutely requires religious sensitivity from the programme and staff, it was in fact easier for the NGO not to be identified as a religious institution when engaging with religiously sensitive issues - both in terms of community perceptions and also as it was helpful that the institution did not bring its own theology to the engagement. (This kind of finding will be highly challenging to some of the religion and development advocacy proponents who have argued vigorously that religious development institutions are better equipped to deal with religious communities because of their own religious character and internal theology). Leurs (2012) is one of the few that directly questions whether religious and secular NGOs are distinctive (comparing AIDS-engaged NGOs in Nigeria). This study is relatively descriptive (so does not directly assess impact), and Leurs' conclusions are not surprising. He finds that although the religious NGO staff perceived their institution and work to have distinctive features, there were relatively few observable differences. He concludes:
... a standardised donor preference for FBOs is inappropriate and may be counter-productive, since NGOs cannot be simply categorised as 'religious' or 'secular', there is still insufficient evidence to assess the outcomes and impact of their HIV or AIDS-related activities, and their effectiveness is influenced not only by their characteristics and strategies but also by the context in which they operate. (Leurs 2012:704)

Part of the problem is that the advocacy movement has made a strong claim without evidence (of the sort recognised by the development sector) to back it up. However, clearly those engaged in this advocacy have also not prioritised or resourced research that could have supported these claims. We will return to issues of evidence shortly - however, there is a more fundamental concern here. Have we (the broad range of actors engaged in this advocacy) not inadvertently set ourselves up for failure on a more fundamental level that is, by the very division created between religious and 
secular entities and NGOs in this comparative advocacy effort? For years, authors have been questioning this binary division and have argued vigorously that it simply does not make sense in most development contexts. For example, consider the titles of these articles: 'A call for clarification and critical analysis of the work of faith-based development organisations' (Bradley 2009); 'Religious and faith-based organisations: Do we know one when we see one?' (Jeavons 2004); or 'An FB-oh?' (Olivier 2011). However, such calls have gone largely unheard (see also Berger 2003; Clarke 2006; Deneulin \& Rakodi 2011; Sider \& Unruh 2004; Unruh 2004). The confusion is exemplified in this statement from a symposium report from the Center for International and Regional Studies (CIRS 2008):

\footnotetext{
... the group focused initially on exploring the significance that should be given to the terms and concepts of 'faith', 'faith-based', and 'faith-inspired', and the significance of describing organisations or communities as Muslim or Islamic, or nondenominational or secular ... [and was admonished] to pay special attention to vocabulary and especially terms that may be imbued with western framing and historical legacies ... The crux of the issue lies less in how an individual or an organisation defines their 'faith' motivations than on how others interpret and assess its significance. The topic is strewn with pitfalls, and virtually all terms and categories are slippery and problematic. (p. 7)
}

This is an area of continued and unresolved debate within this advocacy effort. New typologies and definitions have been created - but these never resolve the underlying problems created by the initial binary classification. For example, attempts have been made to classify religious entities by type, form, religiosity and level (usually returning to the simple identifier of whether they self-declare as religious or not). However, research continues to show that such classifications are inadequate to hold the variety of entities that appear in development contexts. Even the classic forms of civil society institutions (such as NGOs) are fluid and complex and adapt with time. For example, institutions that have been labelled as secular NGOs are often more religious in character than those that have been labelled as FBOs. In a workshop in Uganda, a participant had trouble distinguishing between FBOs and NGOs in a local mapping exercise and insisted in frustration that 'all organisations in Uganda are faith-based' (in Olivier \& Wodon 2012a). Conversely, the Aga Khan Development Network, a large and powerful Islamic development agency, has for years resisted being included as part of the faith sector. It is not useful to rehash this extensive area of debate further here but it is important to understand that this classification and naming of things is fundamentally about power. The Cartesian division between religious and secular has been imposed on development contexts by the (northern) powers within development (and within this advocacy effort). Local actors have manoeuvred as best they can in this space, selecting into this framing based on their interpretation of whether it is beneficial to be named as faith-based. However, it is still a contested and uncomfortable space (see Olivier 2014b, 2015; Olivier \& Wodon 2012a).
There is likely not much that can be done with this framing now. However, I would argue that the religion and development advocacy voice has been complicit in supporting this framing - even to the detriment of the underlying cause within that advocacy effort (of promoting the full contribution of religion to development). The distinction between FBO and NGO was made early in the advocacy effort, and it was supported by the push to ensure that proper recognition was made and fair resourcing was given to a particular type of FBO. For example, part of the advocacy effort targeted institutions such as PEPFAR, the Global Fund or USAID and pushed for the creation of distinctly religious categories in these institutional databases (see WHO-CIFA 2014). While successful from an advocacy standpoint, it is possible that those of us engaged in this effort have been 'hoist by our own petard'. That is, while being successful in showing the distinctive support and presence of FBOs in development, we might have actually been complicit in the process of 'boxing' religion into a more confined space in development thinking and practice. This effectively removes from the development gaze all of the more complex ways that religion influences everyday life in development contexts, the weird and wonderful religious entities that do not fit neat categorisations, or issues such as how religion initiates or influences development action in 'secular' institutions.

\section{More evidential dead ends}

Because of the earlier religion-blindness of development, there were (and still are) major evidence gaps that needed to be filled. A substantial research industry has emerged, as demonstrated by the number of institutionally funded reports and studies (see Table 1), as well as by specific grants, such as the DFID grant to the University of Birmingham from 2005-2010, supporting a large programme of research work on religion and development (see Deneulin \& Rakodi 2011; Leurs, Tumaini-Mungu \& Mvungi 2011; Rakodi 2007). It is not possible to make a judgment here on whether the support for research was 'enough' against the obvious lack of evidence. Rather, it is important to understand that the religion and development advocacy agenda drove and resourced this research agenda in a very particular direction, focusing almost exclusively on demonstrating the 'distinctiveness' of religious entities (mainly institutions), rather than how religion and religious institutions fit into development practice or systems. In my assessment, this particular direction given to the research agenda within the advocacy effort has led to something of a dead end for this advocacy effort. Despite a massively increased number of research studies and publications (as demonstrated in these databases), there are still strong calls from within the development sector for 'more and better evidence' to substantiate improved engagement - for example, saying, '[t]he World Bank's relationship with FBOs has transitioned from a specific focus on dialogue with faith leaders to more policy-relevant empirical work with FBOs and country teams' (WHO-CIFA 2009:17-18). 
There are five underpinning issues that need attention. Firstly, as noted earlier, the advocacy effort ran several years ahead of the actual development of an evidence base to support this argument. In fact, the advocacy effort saw success in relation to increased funding allocation ahead of the research and evidence-building effort kicking in. For example, Olivier and Wodon analyse comparative HIV/AIDS funding data and argue that '[i]ncreased funding for FBOs came several steps ahead of attempts to fill the knowledge gap, and actions were taken despite little supporting evidence for targeted engagement' (2014:30). Liebowitz (2004) concurs:

[I]ncreasing resources are being devoted to supporting FBOs in global campaigns ... Yet remarkably little guidance is available for policy makers on exactly what the strengths of FBOs are, what best practices have allowed specific FBOs to achieve significant successes, and how FBOs can be integrated into broader campaigns for prevention and mitigation ... (p. 4)

What this means is that for years, claims for the unique contribution of religious entities were being made without any evidential backing, as there was a substantial case of 'lagging scholarship'. This made it easy for development actors to push back against such claims (Olivier \& Wodon 2012a). For example, as one actor asked, 'How can we expect donors and governments to invest in "unknown" or spurious services based on anecdotal evidence alone?' (WHO-CIFA 2009). This is not presented here as an issue of blame - but rather one of bad timing. The evidence required by the advocacy push was simply not available, and there was no time to wait for it to be developed. However, this has resulted in a significant distrust of evidence emerging out of the faith sector, and as a result has created a knowledgetranslation barrier between the research that has emerged and decision-making.

Secondly, there has been continued engagement about the forms of evidence required to further the advocacy effort. Most of the evidence of the contribution of religion to development is based on scoping reviews, with a small proportion made up of qualitative studies and descriptive forms of evidence. There is very little research that has utilised the quantitative or econometric methods commonly wielded within the development sector to affect change on policy or decision-making - such as impact assessments showing effect on commonly held indicators (see Tyndale 2000). It is possible to count the studies that utilise such methods on one hand. This includes, for example, a heavily cited and dated study out of the World Bank by Reinikka and Svensson (2003), which showed that religiously motivated health workers would work for longer hours for less pay; some analysis of household survey data to utilisation and preference for health and education services (see Olivier \& Wodon 2012a; Olivier et al. 2015); and recently a randomised control trial that assessed the effectiveness of a congregationbased intervention on uptake of HIV testing and linkage to care in pregnant women in Nigeria (Ezeanolue et al. 2015). However, such studies are extremely rare. The limited resourcing of research (especially large-scale longer-term research) within the advocacy effort has been focused almost entirely on scoping review studies or qualitative ethnographic studies that have not often provided the comparative 'proof' of the sort recognised within the development sector.

Thirdly, the advocacy effort has at times increased the suspicions of some decision-makers. The distinctive form of some advocacy efforts such as reports, briefs or posters published by international religious development agencies sometimes have come across as self-promotional in intent (as opposed to evidence-based). This problem has been exacerbated by un-evidenced claims of comparative advantage. There is a very fine line between promoting the contribution of religion to development (because it makes sense for development generally) and the promotion of religious institutions so that some of them might achieve greater access to donor funds (see Olivier \& Wodon 2014). This line is not always clear, and many religious institutions have crossed it, perhaps to their own benefit but also often to the detriment of the broader advocacy effort. This can be seen in the increased calls for 'secular evidence' emerging out of the development sector. For example, '... although [churches] are major institutions ... very little secular analysis of their contemporary social capacities and roles is available' (Luker 2004:1). The very idea of secular evidence is highly loaded and is revealing of the issues of power and clashing epistemologies that underpin this advocacy engagement. No research is entirely 'value-free' (even randomised control trials), but in this case the fact that there are multiple agendas at play has caused difficulties to the broader advocacy agenda.

Another evidential challenge is that within this aggressive advocacy space, it is nearly impossible for religious development institutions to reflexively and publicly acknowledge 'failures' in development practice or implementation. That is, there is so much focus on promoting contributions and strengths that there is almost no space to share lessons on things that did not work to plan, or engagement with religious communities that required adjustment on implementation. Assessing these two databases (which include public evaluation reports), there are only a handful that take a critical perspective and even fewer that do so and remain endorsed by the religious institution (see Olivier 2014a). While it is difficult for any competitive agency to admit failure, the overwhelmingly 'positive' discourse of the religion and development advocacy effort makes it even more so for religious agencies. In turn, this then comes across to some development leaders as religious institutions being biased and uncritical, again hampering the translation of evaluative findings back into operational practice.

Finally, one last seeming dead end is the issue of representation. A major effort of the advocacy movement has been to argue for the wide variety of religions and religious influences in development contexts. However, although there has been obvious success at getting religion to the 
development table, this is acknowledged by many to still be a highly limited form of representation (see Duff et al. 2016; Duff \& Buckingham 2015). A decade ago, Clarke (2006) warned that the growing interest in religion and development risked compounding conceptual and programmatic biases already within development discourse - reinforcing the situation where donors have traditionally focused on supporting mainstream Christian organisations and not necessarily engaging with the other types of religious institutions that play an active role in the lives of local communities. This warning still rings true, as the bulk of the engagement is indeed with mainstream Christian institutions and, in a few isolated cases, a particular form of mainstream Islamic development agency. The dominant institutions represented in these advocacy events and publications are institutions such as the Catholic and Anglican Churches and their development agencies (such as the Catholic Agency for Overseas Development and Caritas), Christian Aid, the Salvation Army, Tearfund, World Vision, Cordaid and Islamic Relief.

What has evolved in the development dialogue space is a strange form of 'caste' system in which mainstream religious development agencies (with northern headquarters) and northern-based religious denominational bodies (such as the Salvation Army headquarters in London or New York or the Catholic Church, with headquarters in Italy and Geneva) now have regular and substantial representation at the development table. However, the growing mass of 'other' religious institutions such as charismatics, Pentecostals or sects without a clear hierarchy (and no northern-based office), politicised Islamic groups and others, are rarely present or represented (see Bompani 2010; Mcduie-Ra \& Rees 2010; Renders 2002; Sackey 2001). The results of this configuration is that the 'invited space' (Gaventa 2007) in which this development dialogue occurs remains rarefied and limited. It has also rather neatly removed any discourse on the underlying challenges of engagement with religious communities (such as faith healing), where the actions of religious communities come into direct conflict with development strategies and agendas. (It is therefore problematically suggestive that it is with those 'other religions' where such problems lie.) There is visible reluctance from both development actors and mainstream religious groups to engage too far with these other religious groups. For example, several of the international conferences have concluded that whereas the UN leaders are keen to engage with mainstream religious institutions, they are less willing to work with those others who are more problematic. Mainstream religious development agencies (the most prominent representative type in this advocacy effort) understandably have trouble being representative of these other groups (Olivier \& Wodon 2012a).

This is partially a challenge of representation and partially a challenge of power. It is also a challenge to the religion and development advocacy agenda, since the main argument of the advocacy effort rests on the inclusion of all types of religion and religious groups. In fact, many of the comparative advantage claims (of scope, reach to local community or trust) only ring true if these 'other' religious communities are included. Their exclusion is therefore a conundrum for the entire advocacy effort: the core religious assets that need to be leveraged for effective development work are (arguably) mainly situated in communities that are still 'untouchable' to both development institutions and the mainstream religious groups who are representing the faith sector at the development table.

\section{Conclusions}

It is clear that the religion and development advocacy effort has seen major results. It has effectively proven that religion has relevance to development and has spawned a veritable industry of effort. However, there is some danger in continuing down the same path - and the dead ends identified above are the warning signs before getting lost in the forest. Those engaged in this advocacy effort might now need to practice some (difficult) critical reflection and prepare to gently steer the advocacy effort in a new direction.

The narrative at the beginning of this article is a reminder that religion in development is highly complex. Authors and leaders in this field have, for years, argued that this complexity needs to be acknowledged. However, advocacy does not often leave room for consideration of complexity. It is by nature a process by which messages are simplified and limited for effective communication. If the main argument is 'religion is important to development', is there any room for saying 'but it is also massively complex'? It is useful to remember Peter Berger, who bravely (in my opinion) admitted that he had 'gotten the secularisation thesis wrong' (Berger 1999). A similar courage is now required here: to enjoy the well-earned rewards of a successful advocacy effort but also to reflect on whether we took all the right turns on this journey and whether a new direction might now be needed (and by we, I mean all of those who have been or are involved in this dispersed advocacy endeavour).

If we can believe in our successes - that religion has now been shown to be relevant to development - perhaps it is now possible to shrug off some of the anxiety and bravely face these hard questions, despite the discomfort this will cause. Perhaps, from a position of strength and confidence, this dispersed community of practice could shift to advocating for more complex things: for raising robust evidence, for being self-critical, for examining implementation challenges as well as successes, for broadening out the invited space (even to those more challenging 'others'), for finding a new cutting edge and for considering integrated systems rather than comparing differences.

\section{Acknowledgements Competing interests}

The author declares that she has no financial or personal relationships that may have inappropriately influenced her in writing this article. 


\section{References}

Ager, A. \& Ager, J., 2016, 'Sustainable development and religion: Accommodating diversity in a post-secular age', Review of Faith and International Affairs 14(3) 101-105.

Bateman, N., 2000, Advocacy skills for health and social care professionals, Jessica Kingsley Publishers, London.

Belshaw, D., Calderisi, R. \& Sugden, C. (eds.), 2001, Faith in development: Partnership between the World Bank and the churches of Africa, Regnum Books International, Oxford.

Benn, C., 2003, Why religious health assets matter. ARHAP: Assets and Agency Colloquium, African Religious Health Assets Programme (ARHAP), Pietermaritzburg South Africa.

Berger, J., 2003, 'Religious nongovernmental organisations: An exploratory analysis', Voluntus: International Journal of Voluntary \& Nonprofit Organisations 14, 15-39. http://dx.doi.org/10.1023/A:1022988804887

Berger, P.L., 1999, 'The desecularisation of the world: a global overview', in P.L. Berger (ed.), The desecularisation of the world: resurgent religion and world politics, pp. 1-18, Ethics and Public Policy Centre, Washington, DC.

Blevins, J. \& Griswold, E., 2014, Essential partners: The scope of the contributions of faith-based health systems to HIV prevention, treatment, and support in Kenya, Interfaith Health Program, Emory University, Atlanta, GA.

Boehle, J., 2010, 'The UN system and religious actors in the context of global change', CrossCurrents 60, 383-401. http://dx.doi.org/10.1111/j.1939-3881.2010.00138.x

Bompani, B., 2010, 'Religion and development from below: Independent Christianity in South Africa', Journal of Religion in Africa 40, 307-330. http://dx.doi. org/10.1163/157006610X525435

Bonney, R. \& Hussain, A., 2001, Faith communities and the development agenda, Department for International Development (DFID), London, UK.

Botchwey, N.D., 2007, 'The religious sector's presence in local community development', Journal of Planning Education and Research 27, 36-48. http://dx. development', Journal of Planning Educd
doi.org/10.1177/0739456X07299948

Bradley, T., 2009, 'A call for clarification and critical analysis of the work of faith-based development organisations (FBDO)', Progress in Development Studies 2, 101-114. $\mathrm{http}: / / d x . d o i . o r g / 10.1177 / 146499340800900202$

Buijs, G. \& Kasambala, A., 2008, 'Religion, secularism and development: Shortcircuits about HIV/AIDS', in S. De Gruchy, N. Koopman \& S. Strijbos (eds.), From our side: Emerging perspectives on development and ethics, pp. 223-242, Rozenberg Publishers, Amsterdam.

Carbonnier, G. (ed.), 2013, International development policy: Religion and development, Palgrave Macmillan, Basingstoke.

Center for International and Regional Studies (CIRS), 2008, CIRS Symposium: Globa development and faith-inspired organisations in the Muslim world, 17 Decembe 2008, Center for International and Regional Studies (CIRS) and The Berkley Cente for Religion, Peace and World Affairs, Doha, Qatar.

Clarke, G., 2006, 'Faith matters: Faith-based organisations, civil society and international development', Journal of International Development 18, 835-848. http://dx.doi.org/10.1002/jid.1317

Clarke, G., 2007, 'Agents of transformation? Donors, faith-based organisations and international development', Third World Quarterly 28, 77-96. http://dx.doi. org/10.1080/01436590601081880

De Gruchy, S., Jones, D., Cochrane, J.R., Germond, P., Gunderson, G., Matimelo, S et al., 2006, Appreciating assets: The contribution of religion to universal access in Africa, African Religious Health Assets Programme (ARHAP) for the World Health Organisation, Cape Town, South Africa.

Deneulin, S. \& Rakodi, C., 2011, 'Revisiting religion: Development studies thirty years on', World Development 39, 45-54. http://dx.doi.org/10.1016/j.worlddev. 2010.05.007

Department for International Development, 2006, Faith in development position paper, The Department for International Development (DFID), London.

Dicklitch, S. \& Rice, H., 2004, 'The Mennonite Central Committee (MCC) and faith based NGO aid to Africa', Development in Practice 14, 660-672. http://dx.doi. org/10.1080/0961452042000239805

Duff, J.F., Battcock, M., Karam, A. \& Taylor, A.R., 2016, 'High-level collaboration between public sector and religious and faith-based organisations: Fad or trend?', Review of Faith and International Affairs 14(3), 95-100.

Duff, J.F. \& Buckingham, W.W., 2015, 'Strengthening of partnerships between the public sector and faith-based groups', The Lancet 386, 1786-1794. http://dx.doi. org/10.1016/S0140-6736(15)60250-1

Ezeanolue, E.E., Obiefune, M.C., Ezeanolue, C.O., Ehiri, J.E., Osuji, A., Ogidi, A.G. et al. 2015, 'Effect of a congregation-based intervention on uptake of HIV testing and linkage to care in pregnant women in Nigeria (Baby Shower): A cluster randomised trial', The Lancet Global Health 3, e692-e700. http://dx.doi.org/10.1016/S2214109X(15)00195-3

Formicola, J.R., Segers, M. \& Weber, P., 2003, Faith-based initiatives and the Bush administration: The good, the bad and the ugly, Rowman and Littlefield Publishers, Lanham, MD

Foster, G., 2004, Study of the response by faith-based organisations to orphans and vulnerable children, World Conference of Religions for Peace (WCRP), New York.

Gaventa, J., 2007, 'Forward', in A. Cornwall \& V.S. Coelho (eds.), Spaces for change? The politics of citizen participation in new democratic arenas, $\mathrm{pp}$. $\mathrm{x}-\mathrm{xvii}$, Zed Books, London.
Germond, P., 2001, 'Theology, development and power: Religious power and development practice', Journal of Theology for Southern Africa 110, 21-31.

Ghatak, A., 2006, 'Faith, work, and women in a changing world: The influence of religion in the lives of beedi rollers in West Bengal', Gender and Development 14 375-383. http://dx.doi.org/10.1080/13552070600980468

Global Fund to Fight AIDS, Tuberculosis and Malaria, 2008, Report on the involvement of faith-based organsations in the Global Fund, The Global Fund to Fight AIDS, Tuberculosis and Malaria, Geneva, Switzerland.

Haakenstad, A., Johnson, E., Graves, C., Olivier, J., Duff, J. \& Dieleman, J.L., 2015 'Estimating the development assistance for health provided to faith-based organisations, 1990-2013', PLoS One 10, 1-16. http://dx.doi.org/10.1371/journal. pone.0128389

James, R., 2011, 'Handle with care: Engaging with faith-based organisations in development', Development in Practice 21(1), 109-117. http://dx.doi.org/10.108 0/09614524.2011.530231

Jeavons, T.H., 2004, 'Religious and faith-based organisations: Do we know one when we see one?', Nonprofit and Voluntary Sector Quarterly 33, 140-145. http:// dx.doi.org/10.1177/0899764003257499

Joint Learning Initiative on Faith and Local Communities (JLIF\&LC), 2015, 'Religion in sustainable development: building partnerships to end extreme poverty', in A. Chaudhry, H. Manguerra, R. Holland \& J. Duff (eds.), Religion and Sustainable Development: Building Partnerships to End Extreme Poverty, 7-9 July 2015, Join Learning Initiative on Faith and Local Communities (JLIF\&LC), Washington, DC.

Karam, A., 2010, 'The United Nations Populations Fund's (UNFPA) legacy: Engaging faith-based organisations as cultural agents of change for the MDGs', CrossCurrents 60, 432-450. http://dx.doi.org/10.1111/j.1939-3881.2010.00141.x

Karam, A., Clague, J., Marshall, K. \& Olivier, J., 2015, 'The view from above: Faith and health', The Lancet 386, 22-24. http://dx.doi.org/10.1016/S0140-6736(15) 61036-4

Kearns, K., Park, C. \& Yankoski, L., 2005, 'Comparing faith-based and secular community service corporations in Pittsburgh and Allegheny County, Pennsylvania', Nonprofit and Voluntary
dx.doi.org/10.1177/0899764004269306

Kessler, E. \& Arkush, M., 2008, Keeping faith in development: The significance of interfaith relations in the work of humanitarian aid and international development organisations, The Woolf institute of Abrahamic Faiths, Cambridge.

Krige, S., 2008, 'Towards a coherent vision for faith-based development', Journal of Theology for Southern Africa 16, 16-37.

Lee, C., Brewster-Lee, D., Devine, B. \& Bingham, G., 2003, Global fund responsiveness to faith-based organisations, Christian Connections for International Health $(\mathrm{CClH})$, Sterling VA.

Leurs, R., 2012, 'Are faith-based organisations distinctive? Comparing religious and secular NGOs in Nigeria', Development in Practice 22, 704-720. http://dx.doi.org/ 10.1080/09614524.2012.685868

Leurs, R., Tumaini-Mungu, P. \& Mvungi, A., 2011, Mapping the development activities of faith-based organisations in Tanzania, Working Paper, University of Birmingham, Birmingham.

Liebowitz, J., 2004, Faith-based organisations and HIV/AIDS in Uganda and KwaZuluNatal, Health Economics and HIV/AIDS Research Division (HEARD), University of KwaZulu-Natal, Durban.

Luker, V., 2004, 'Civil society, social capital and the churches: HIV/AIDS in Papua New Guinea', State, Society and Governance in Melanesia Project, University of South Pacific, Suva, Fiji.

Marshall, K., 2001, 'Development and religion: A different lens on development debates', Peabody Journal of Education 76, 339-375. http://dx.doi.org/10.1080/ 0161956X.2001.9682003

Marshall, K., Bohnett, T. \& Filsinger, A., 2009, Faith inspired organisations and global development: 'Mapping' social economic development work in Latin America, Georgetown University's Berkley Center for Religion, Peace, and World Affairs, Georgetown University's Berk

Marshall, K. \& Keough, L., 2005, Finding global balance: Common ground between the worlds of development and faith, World Bank, Washington, DC.

Marshall, K. \& Van Saanen, M., 2007, Development and faith: where mind, heart, and soul work together, World Bank, Washington, DC.

Mcduie-Ra, D. \& Rees, J.A., 2010, 'Religious actors, civil society, and the development agenda: The dynamics of inclusion and exclusion', Journal of International Development 22, 20-36. http://dx.doi.org/10.1002/jid.1537

Melkote, S.R. \& Steeves, H.L., 2001, Communication for development in the third world: Theory and practice for empowerment, Sage, London.

Olivier, J., 2010, In search of common ground for interdisciplinary collaboration and communication: Mapping the cultural politics of religion and HIV/AIDS in subSaharan Africa, PhD thesis, University of Cape Town, Cape Town South Africa.

Olivier, J., 2011, 'An FB-oh?: Mapping the etymology of the religious entity engaged in health', in J.R. Cochrane, B. Schmid \& T. Cutts (eds.), When religion and health align: Mobilising religious health assets for transformation, Cluster Publications, Pietermartizburg.

Olivier, J., 2014a, Hierarchical but decentralised: Governance practices among Catholic health providers in Ghana, Cameroon and Malawi, International Religious Health Assets Programme, University of Cape Town, for Cordaid, Cape Town, South Africa.

Olivier, J., 2014b, 'Mapping interdisciplinary communication between the disciplines of religion and public health in the context of HIV/AIDS in Africa', Religion and Theology 21, 251-289. http://dx.doi.org/10.1163/15743012-02103003 
Olivier, J., 2015, 'Religion at the intersection of development and public health in development contexts: From advocacy about faith-based organisations to systems thinking', in E. Tomalin (ed.), The Routledge handbook of religions and global development, pp. 346-358, Routledge, London.

Olivier, J., Haddad, B., Leonard, G.S.D. \& Schmid, B., 2016, The cartography of HIV and AIDS, religion and theology: A partially annotated bibliography, The Collaborative for HIV and AIDS, Religion and Theology (CHART), School of Religion and Theology, University of KwaZulu-Natal, Pietermaritzburg, South Africa.

Olivier, J. \& Paterson, G.M., 2011, 'Religion and medicine in the context of HIV and AIDS: A landscaping review', in B. Haddad (ed.), Religion and HIV and AIDS: Charting the terrain, University of KwaZulu-Natal Press, Scottsville, South Africa.

Olivier, J., Schmid, B. \& Cochrane, J.R., 2016, The 'semi-bounded' field of religion and public health: An ongoing review and bibliography, The International Religious Health Assets Programme (IRHAP), University of Cape Town, Cape Town, South Africa.

Olivier, J. \& Smith, S., 2016, 'Innovative faith-community responses to HIV and AIDS: Summative lessons from over two decades of work', Review of Faith and International Summative lessons from over two decades of work', Review of Faith and

Olivier, J., Tsimpo, C., Gemignani, R., Shojo, M., Coulombe, H., Dimmock, F. et al., 2015, 'Understanding the roles of faith-based health-care providers in Africa: Review of the evidence with a focus on magnitude, reach, cost, and satisfaction' The Lancet 386, 1765-1775. http://dx.doi.org/10.1016/S0140-6736(15)60251-3

Olivier, J. \& Wodon, Q., 2012a, 'Layers of evidence: Discourses and typologies of faithinspired community responses to HIV/AIDS in Africa', in J. Olivier \& Q. Wodon (eds.), Strengthening faith-inspired health engagement, Vol 3: Mapping, cost, and reach to the poor of faith-inspired health care providers in sub-Saharan Africa, HNP Discussion Papers, The World Bank, Washington, DC.

Olivier, J. \& Wodon, Q., 2012b, 'Playing broken telephone: Assessing faith-inspired health care provision in Africa', Development in Practice 22, 819-834. http://dx. doi.org/10.1080/09614524.2012.685870

Olivier, J. \& Wodon, Q., 2014, 'Increased funding for AIDS-engaged faith-based organisations in Africa?', The Review of Faith \& International Affairs 12, 53-71. http://dx.doi.org/10.1080/15570274.2013.876736

Pallas, C.L., 2005, 'Canterbury to Cameroon: A new partnership between faiths and the World Bank', Development in Practice 15, 677-684. http://dx.doi.org/ 10.1080/09614520500129248

Para-Mallam, O.J., 2006, 'Faith, gender and development agendas in Nigeria: Conflicts, challenges, and opportunities', Gender \& Development 14, 409-421. http://dx. doi.org/10.1080/13552070600980898

President's Emergency Plan for AIDS Relief (PEPFAR), 2009, Working with community based and faith-based organisations, The President's Emergency Plan for AIDS Relief (PEPFAR), Washington, DC.

Platteau, J., 2008, 'Religion, politics, and development: Lessons from the lands of Islam', Journal of Economic Behavior \& Organisation 68, 329-351. http://dx.doi. org/10.1016/j.jebo.2008.06.003

Rakodi, C., 2007, Understanding the roles of religion in development, Religions and Development Working paper 9, University of Birmingham, Birmingham, UK.

Reinikka, R. \& Svensson, J., 2003, Working for God? Evaluating service delivery of religious not-for-profit health care providers in Uganda, World Bank, Washington, DC.

Renders, M., 2002, 'An ambiguous adventure: Muslim organisations and the discourse of "development" in Senegal', Journal of Religion in Africa 32, 61-82. http://dx. doi.org/10.1163/15700660260048474

Rew, M., 2011, 'Religion and development I: Anthropology, Islam, transnationalism and emerging analyses of violence against women', Progress in Development Studies 11, 69-76. http://dx.doi.org/10.1177/146499341001100105
Sackey, B.M., 2001, 'Charismatics, independents, and missions: Church proliferation in Ghana', Culture and Religion 2, 41-59. http://dx.doi.org/10.1080/014383001 08567162

Schmid, B., Thomas, E., Olivier, J. \& Cochrane, J.R., 2008, The contribution of religious entities to health in sub-Saharan Africa, African Religious Health Assets Programme, Cape Town, South Africa.

Sider, R.J. \& Unruh, H.R., 2004, 'Typology of religious characteristics of social service and educational organisations and programs', Nonprofit and Voluntary Sector Quarterly 33, 109-134. http://dx.doi.org/10.1177/0899764003257494

Taylor, N., 2005a, Many clouds, little rain? The Global Fund and local faith-based responses to HIV and AIDS, Tearfund, Teddington, UK.

Taylor, N., 2005b, The warriors and the faithful: The World Bank MAP and local faithbased initiatives in the fight against HIV and AIDS, Tearfund, Teddington, UK.

Taylor, N., 2006, Working together? Challenges and opportunities for international development agencies and the church in the response to AIDS in Africa, Tearfund, Teddington, UK.

Tearfund, 2006, Faith untapped: Why churches can play a crucial role in tackling HIV and AIDS in Africa, Tearfund, Teddington, UK.

Ter Haar, G. \& Ellis, S., 2006, 'The role of religion in development: Towards a new relationship between the European Union and Africa', The European Journal of Development Research 18, 351-367. http://dx.doi.org/10.1080/0957 8810600893403

Thomas, S.M., 2004, 'Building communities of character: Foreign aid policy and faithbased organisations', SAIS Review 24, 133-148. http://dx.doi.org/10.1353/ sais.2004.0045

Tomalin, E. (ed.), 2015, The Routledge handbook of religions and global development Routledge, London.

Tyndale, W., 2000, 'Faith and economics in "development": A bridge across the chasm', Development in Practice 10, 9-18. http://dx.doi.org/10.1080/096145200 52466

United Nations Population Fund (UNFPA), 2008, Culture matters: Lessons from a legacy of engaging faith-based organisations, United Nations Population Fund (UNFPA), New York.

Unruh, H.R., 2004, 'Religious elements of church-based social service programs: Types, variables and integrative strategies', Review of Religious Research 45, 317-335. http://dx.doi.org/10.2307/3511989

Vitillo, R.J., 2009, 'Faith-based responses to the global HIV pandemic: Exceptional engagement in a major public health emergency', Journal of Medicine and the Person 7, 77-84. http://dx.doi.org/10.1007/s12682-009-0020-3

Woldehanna, S., Ringheim, K., Murphy, C., Keikelame, M.J., Gibson, J., Odyniec, G. et al., 2005, Faith in action: Examining the role of faith-based organisations in addressing HIV/AIDS - A multi country key informant survey, Global Health Council, Washington, DC.

World Faiths Development Dialogue (WFDD), 2012, Global health and Africa: Assessing faith work and research priorities, World Faiths Development Dialogue (WFDD) for the Tony Blair Faith Foundation (TBFF), Washington, DC.

World Health Organisation (WHO), 2004, 'Faith-based groups: Vital partners in the battle against AIDS', The '3 by 5' Target, July-August, p. 1-6.

World Health Organsation and Center for Interfaith Action on Global Poverty (WHO-CIFA), 2009, Report on WHO-CIFA consultation: NGO mapping standards describing religious health assets, Chateau de Bossey, Bogis-Bossey, Switzerland. 